Jurnal Sulolipu : Media Komunikasi Sivitas Akademika dan Masyarakat

Vol. 20 No. 12020

e-issn : 2622-6960, p-issn : 0854-624X

\title{
KEMAMPUAN EKSTRAK DAUN BELUNTAS (Pluchea indica linn) DALAM MEMATIKAN JENTIK NYAMUK Aedes aegypti
}

Hasni, Rafidah

\author{
Jurusan Kesehatan Lingkungan Poltekkes Kemenkes Makassar \\ (hasni.nini18@gmail.com)
}

\begin{abstract}
Aedes aegypti mosquito is considered as the main vector that causes This causes Dengue Hemorrhagic Fever (DHF). The purpose of this study was to determine the ability of beluntas (Pluchea indica linn) leaf extract kill Aedes aegypti mosquito larvae and this type of research was a quasi-experiment. At each concentration, 20 larvae of the Aedes aegypti mosquito were given, and the control counted every 60 minutes for 24 hours, with repetitions of 3 replications. The results of the study using the beluntas leaf extract ingredients which of course with various concentrations of $0.5 \%$ can kill larvae with an average mortality of $50 \%$, the concentration of $0.75 \%$ average mortality rate of $50 \%$, the concentration of $1.00 \%$ on average larvae mortality of $55 \%$, the concentration of $1.25 \%$ average mortality of $50 \%$, the concentration of $1.5 \%$, average mortality rate of $50 \%$. The conclusion in this study is that the beluntas (Pluchea indica linn) leaf extract can kill the larvae of the Aedes aegypti mosquito. The suggestions in this study are expected to be an alternative vector control especially for the larvae of Aedes aegypti, beluntas leaves can be used as vegetable insecticides because they are safe for the environment and humans.
\end{abstract}

Keywords: Beluntas leaf extract, larvae of Aedes aegypti mosquito

ABSTRAK

Jentik nyamuk Aedes aegypti dianggap sebagai vektor utama penyebab terjadinya penyakit Demam Berdarah Dengue (DBD). Tujuan dalam penelitian ini adalah untuk mengetahui kemampuan ekstrak daun beluntas (Pluchea indica linn) dalam mematikan jentik nyamuk Aedes aegypti dan jenis penelitian ini adalah eksperimen quasi. Pada masing-masing konsentrasi diberikan 20 ekor jentik nyamuk Aedes aegypti, dan begitupun pada kontrol yang dihitung kematiannya setiap 60 menit selama 24 jam, dengan pengulangan sebanyak 3 kali replikasi.Hasil penelitian dengan menggunakan bahan ekstrak daun beluntas yang tentunya dengan berbagai macam konsentrasi yaitu 0,5\% dapat mematikan jentik dengan rata-rata kematian $50 \%$, konsentrasi $0,75 \%$ rata-rata kematian jentik $50 \%$, konsentrasi $1,00 \%$ rata-rata kematian jentik $55 \%$, konsentrasi $1,25 \%$ rata-rata kematian jentik $50 \%$, konsentrasi $1,5 \%$ rata-rata kematian jentik $50 \%$. Kesimpulan dalam penelitian ini adalah ekstrak daun beluntas (Pluchea indica linn) mampu dalam mematikan jentik nyamuk Aedes aegypti. Adapun saran dalam penelitian ini diharapkan dapat menjadi suatu alternative pengendalian vektor khususnya terhadap jentik nyamuk Aedes aegypti, daun beluntas dapat di fungsikan sebagai insektisida nabati karena aman bagi lingkungan dan manusia.

Kata Kunci: Ekstrak Daun Beluntas, Jentik Nyamuk Aedes aegypti

\section{PENDAHULUAN}

Nyamuk Aedes aegypti dianggap sebagai salah satu spesies vektor nyamuk yang paling penting di dunia karena mempunyai kerentanan yang tinggi terhadap infeksi virus. Hal tersebut menyebabkan Aedes aegypti dapat menimbulkan penyakit epidemi pada manusia, termasuk demam berdarah, chikungunya, dan demam kuning. Khususnya, nyamuk spesies ini dianggap sebagai vektor utama penyebab terjadinya penyakit Demam Berdarah Dengue (DBD) (Hafidz, 2017).

Penyakit DBD atau Dengue

Hemorrhagic Fever (DHF) sampai saat ini merupakan salah satu masalah kesehatan masyarakat di Indonesia yang cenderung meningkat jumlah pasien serta semakin luas penyebarannya. Penyakit DBD ini ditemukan hampir di seluruh belahan dunia terutama di negara-negara tropik dan subtropik, baik sebagai penyakit endemik maupun endemik. Kejadian luar biasa (KLB) dengue biasanya terjadi di daerah endemik dan berkaitan dengan datangnya musim hujan, sehingga terjadi peningkatan aktivitas vektor dengue pada musim hujan yang dapat menyebabkan terjadinya penularan penyakit DBD pada manusia melalui vektor Aedes aegypti. (Ariani, 2016).
Manajemen lingkungan adalah upaya pengelolaan lingkungan sehingga tidak kondusif sebagai habitat perkembangbiakan atau dikenal sebagai source reduction seperti $3 \mathrm{M}$ plus (menguras, menutup, mengubur). Selain dari upaya pengendalian $3 \mathrm{M}$ plus dapat juga menggunakan bahan alami untuk mematikan jentik nyamuk Aedes aegypti yang aman bagi lingkungan dan kesehatan yaitu dengan menggunakan daun salam, daun sirih, daun jeruk nipis, serta daun beluntas.

\section{METODE \\ Desain, tempat, dan waktu}

Penelitian ini menggunakan ekstrak daun beluntas (Pluchea indica linn) dengan konsentrasi $(0,5 \%, 0,75 \%, 1,00 \%, 1,25 \%, 1,5 \%)$. Setiap konsentrasi dilakukan sebanyak 3 replikasi dengan menggunakan jentik Aedes aegypti instar III. Lokasi penelitian di laksanakan di Laboratorium Kampus Jurusan Kesehatan Lingkungan Politeknik Kesehatan Makassar. Waktu pelaksanaan, meliputi pengamatan di laboraturium yang dilaksanakan pada bulan Februari-Mei 2019.

\section{Langkah-langkah Penelitian}

Cuci daun beluntas sampai bersih. Kemudian potong daun beluntas hingga menjadi 
potongan kecil, timbang daun beluntas hingga 500 gram. Lalu masukkan daun beluntas yang telah dipotong kecil kedalam bejana meserasi. Kemudian masukkan $500 \mathrm{ml}$ methanol hingga menutupi permukaan daun beluntas dalam bejana setinggi 2-3 $\mathrm{cm}$. Diamkan daun beluntas yang telah direndam selama 5 hari, dan selama peredaman hindarkan dari cahaya matahari. Sekali-kali aduk daun beluntas yang telah direndam dengan methanol. Setelah direndam selama 5 hari, saring daun beluntas dengan menggunakan saringan untuk memisahkan ampas daun beluntas dengan ekstraknya. Kemudian ampas daun beluntas direndam kembali menggunakan methanol dan diamkan selama 5 hari, hal ini dilakukan sebanyak 2 kali agar ekstrak yang diperoleh sempurna. Setelah daun beluntas direndam selama 10 hari, saring kembali untuk memisahkan ampasnya. Kemudian hasil rendaman tersebut diuapkan diatas water bath sampai menghasilkan cairan kental yang disebut ekstrak. Setelah jadi ekstrak timbang ekstrak tersebut sesuai konsentrasi yang digunakan. Misalnya untuk mendapatkan $100 \mathrm{ml}$ ekstrak daun beluntas konsentrasi 0,5\% yaitu maka 0,5 gr+99,5 ml air. Kemudian masukkan 20 ekor jentik nyamuk Aedes aegypti pada setiap wadah yang sudah ditentukan konsentrasi ekstraknya. Lakukan pengamatan terhadap jentik, hitung berapa jentik yang mati setiap 1 jam selama 24 jam dengan percobaan sebanyak 3 kali replikasi.

\section{Bahan dan alat}

Bahan yang digunakan dalam penelitian ini adalah daun beluntas, methanol, air, dan jentik nyamuk Aedes aegypti sebanyak 360 ekor untuk 3 kali replikasi. Alat yang digunakan yaitu timbangan, gelas ukur, bejana meserasi, saringan, water bath, stopwatch, wadah.

\section{Pengolahan Data}

Pengolahan data dilakukan secara manual dan dibantu dengan alat hitung, data yang diperoleh dari hasil pengamatan saat pelaksanaan eksperimen, disajikan dalam bentuk tabel, persentase, dan grafik hasil penelitian disertai uraian-uraian yang didasarkan pada teori pendukung.

HASIL

Berdasarkan penelitian yang telah dilaksanakan di laboratorium Jurusan Kesehatan Lingkungan Poltekkes Kemenkes Makassar pada bulan Mei 2019 mengenai kemampuan ekstrak daun beluntas (Pluchea indica linn) dalam mematikan jentik Aedes aegypti. Hasil penelitian dengan menggunakan berbagai macam konsentrasi yaitu konsentrasi 0,5\%, konsentrasi $0,75 \%$, konsentrasi $1,00 \%$, konsentrasi $1,25 \%$, konsentrasi $1,5 \%$, setiap konsentrasi tersebut menggunakan $200 \mathrm{ml}$ air dengan sampel 20 ekor jentik Aedes aegypti dan pada setiap konsentrasi dilakukan pengamatan pada jentik setiap 1 jam dalam waktu 24 jam, kemudian dilakukan percobaan sebanyak 3 kali replikasi. Banyaknya konsentrasi ekstrak daun beluntas mempunyai daya bunuh yang berbeda pula pada jentik Aedes aegypti yang mati sampai tingkat konsentrasi yang telah ditentukan sehingga dapat dilihat pada tabel sebagai berikut:

Tabel 1

Hasil Pengamatan Jentik Aedes aegypti Setelah Pemajanan Dengan Konsentrasi 0,5\% Ekstrak Daun Beluntas Selama 24 Jam Dengan Interval Waktu 1 Jam

\begin{tabular}{|c|c|c|c|c|c|c|c|}
\hline \multirow{2}{*}{ No } & \multirow{2}{*}{$\begin{array}{l}\text { Waktu } \\
\text { (Jam) }\end{array}$} & \multicolumn{3}{|c|}{ Jumlah Kematian Jentik } & \multirow{2}{*}{ Kontrol } & \multirow{2}{*}{$\begin{array}{l}\text { \& Rata-rata } \\
\text { kematian } \\
\text { jentik }\end{array}$} & \multirow{2}{*}{$\%$} \\
\hline & & Replikasi & $\begin{array}{c}\text { Replikasi } \\
\text { II }\end{array}$ & $\begin{array}{c}\text { Replikasi } \\
\text { III }\end{array}$ & & & \\
\hline 1 & $1 \mathrm{jam}$ & 0 & 0 & 0 & 0 & 0 & 0 \\
\hline 2 & $2 \mathrm{am}$ & 0 & 0 & 0 & 0 & 0 & 0 \\
\hline 3 & $3 \mathrm{jam}$ & 0 & 0 & 0 & 0 & 0 & 0 \\
\hline 4 & 4 jam & 2 & 1 & 2 & 0 & 2 & 10 \\
\hline 5 & $5 \mathrm{jam}$ & 3 & 2 & 3 & 0 & 3 & 15 \\
\hline 6 & $6 \mathrm{jam}$ & 5 & 4 & 5 & 0 & 5 & 25 \\
\hline 7 & $7 \mathrm{jam}$ & 7 & 6 & 7 & 0 & 7 & 35 \\
\hline 8 & $8 \mathrm{jam}$ & 9 & 8 & 9 & 0 & 9 & 45 \\
\hline 9 & $9 \mathrm{jam}$ & 10 & 9 & 10 & 0 & 10 & 50 \\
\hline 10 & $10 \mathrm{jam}$ & 12 & 11 & 12 & 0 & 12 & 60 \\
\hline 11 & $11 \mathrm{jam}$ & 13 & 12 & 13 & 0 & 13 & 65 \\
\hline 12 & $12 \mathrm{jam}$ & 15 & 14 & 15 & 0 & 15 & 75 \\
\hline 13 & $13 \mathrm{jam}$ & 16 & 15 & 16 & 0 & 16 & 80 \\
\hline 14 & $14 \mathrm{jam}$ & 17 & 16 & 17 & 0 & 17 & 85 \\
\hline 15 & $15 \mathrm{jam}$ & 18 & 17 & 18 & 0 & 18 & 90 \\
\hline 16 & $16 \mathrm{jam}$ & 20 & 20 & 20 & 0 & 20 & 100 \\
\hline
\end{tabular}

Tabel 2

Hasil Pengamatan Jentik Aedes aegypti Setelah Pemajanan Dengan Konsentrasi 0,75\% Ekstrak Daun Beluntas Selama 24 Jam Dengan Interval Waktu 1 Jam

\begin{tabular}{|c|c|c|c|c|c|c|c|}
\hline \multirow{2}{*}{ No } & \multirow{2}{*}{$\begin{array}{l}\text { Waktu } \\
\text { (Jam) }\end{array}$} & \multicolumn{3}{|c|}{ Jumlah Kematian Jentik } & \multirow{2}{*}{ Kontrol } & \multirow{2}{*}{$\begin{array}{c}\text { ¿Rata- } \\
\text { rata } \\
\text { kematian } \\
\text { jentik }\end{array}$} & \multirow{2}{*}{$\%$} \\
\hline & & $\underset{1}{\text { Replikasi }}$ & $\begin{array}{c}\text { Replikasi } \\
\|\end{array}$ & $\begin{array}{l}\text { Replikasi } \\
\text { III }\end{array}$ & & & \\
\hline 1 & $1 \mathrm{jam}$ & 0 & 0 & 0 & 0 & 0 & 0 \\
\hline 2 & 2 jam & 0 & r & 0 & 0 & 0 & 0 \\
\hline 3 & $3 \mathrm{jam}$ & 1 & 1 & 1 & 0 & 1 & 5 \\
\hline 4 & $4 \mathrm{jam}$ & 2 & 1 & 2 & 0 & 2 & 10 \\
\hline 5 & $5 \mathrm{jam}$ & 4 & 3 & 4 & 0 & 4 & 20 \\
\hline 6 & $6 \mathrm{jam}$ & 6 & 6 & 5 & 0 & 6 & 30 \\
\hline 7 & $7 \mathrm{jam}$ & 8 & 7 & 8 & 0 & 8 & 40 \\
\hline 8 & $8 \mathrm{jam}$ & 10 & 9 & 10 & 0 & 10 & 50 \\
\hline 9 & 9 jam & 11 & 10 & 11 & 0 & 11 & 55 \\
\hline 10 & $10 \mathrm{jam}$ & 13 & 13 & 12 & 0 & 13 & 65 \\
\hline 11 & $11 \mathrm{jam}$ & 15 & 14 & 15 & 0 & 15 & -75 \\
\hline 12 & $12 \mathrm{jam}$ & 17 & 16 & 17 & 0 & 17 & 85 \\
\hline 13 & $13 \mathrm{jam}$ & 18 & 17 & 18 & 0 & 18 & 90 \\
\hline 14 & $14 \mathrm{jam}$ & 20 & 20 & 20 & 0 & 20 & 100 \\
\hline
\end{tabular}

Tabel 3 
Jurnal Sulolipu : Media Komunikasi Sivitas Akademika dan Masyarakat

Vol. 20 No. 12020

e-issn : 2622-6960, p-issn : 0854-624X

Hasil Pengamatan Jentik Aedes aegypti Setelah Pemajanan Dengan Konsentrasi 1,00\% Ekstrak Daun Beluntas Selama 24 Jam Dengan Interval Waktu 1 Jam

\begin{tabular}{|c|c|c|c|c|c|c|c|}
\hline \multirow{2}{*}{ NO } & \multirow{2}{*}{$\begin{array}{l}\text { Waktu } \\
\text { (Jam) }\end{array}$} & \multicolumn{3}{|c|}{ Jumlah Kematian Jentik } & \multirow{2}{*}{ Kontrol } & \multirow{2}{*}{$\begin{array}{c}\text { ¿Rata- } \\
\text { rata } \\
\text { kematian } \\
\text { jentik }\end{array}$} & \multirow{2}{*}{$\%$} \\
\hline & & Replikasi & $\begin{array}{c}\text { Replikasi } \\
\|\end{array}$ & $\begin{array}{c}\text { Replikasi } \\
\text { III }\end{array}$ & & & \\
\hline 1 & 1 jam & 0 & 0 & 0 & 0 & 0 & 0 \\
\hline 2 & $2 \mathrm{jam}$ & 1 & 1 & "'1" & 0 & 1 & 5 \\
\hline 3 & $3 \mathrm{jam}$ & 3 & 2 & 3 & 0 & 3 & 15 \\
\hline 4 & $4 \mathrm{jam}$ & 5 & 4 & 5 & 0 & 5 & 25 \\
\hline 5 & $5 \mathrm{am}$ & 7 & 7 & 6 & 0 & 7 & 35 \\
\hline 6 & $6 \mathrm{jam}$ & 11 & 10 & 11 & 0 & 11 & 55 \\
\hline - & $7 \mathrm{jam}$ & 12 & 11 & 12 & 0 & 12 & 60 \\
\hline 8 & $8 \mathrm{jam}$ & 13 & 12 & 13 & 0 & 13 & 65 \\
\hline 9 & $9 \mathrm{jam}$ & 15 & 13 & 15 & 0 & 15 & 75 \\
\hline 10 & $10 \mathrm{am}$ & 16 & 15 & 16 & 0 & 16 & 80 \\
\hline 11 & $11 \mathrm{jam}$ & 17 & 16 & 17 & 0 & 17 & 85 \\
\hline 12 & $12 \mathrm{jam}$ & 18 & 17 & 18 & ' & 18 & 90 \\
\hline 13 & $13 \mathrm{am}$ & 20 & 20 & 20 & 0 & 20 & 101 \\
\hline
\end{tabular}

Tabel 4

Hasil Pengamatan Jentik Aedes aegypti Setelah Pemajanan Dengan Konsentrasi 1,25\% Ekstrak Daun Beluntas Selama 24 Jam Dengan Interval Waktu 1 Jam

\begin{tabular}{|c|c|c|c|c|c|c|c|}
\hline \multirow{2}{*}{ No } & \multirow{2}{*}{$\begin{array}{l}\text { Waktu } \\
\text { (Jam) }\end{array}$} & \multicolumn{3}{|c|}{ Jumlah Kematian Jentik } & \multirow{2}{*}{ Kontrol } & \multirow{2}{*}{$\begin{array}{c}\Sigma \text { Rata- } \\
\text { rata } \\
\text { kematian } \\
\text { jentik }\end{array}$} & \multirow{2}{*}{$\%$} \\
\hline & & $\begin{array}{c}\text { Replikasi } \\
\text { I }\end{array}$ & $\begin{array}{l}\text { Replikasi } \\
\|\end{array}$ & $\begin{array}{l}\text { Replikasi } \\
\text { III }\end{array}$ & & & \\
\hline 1 & 1 jam & 2 & 2 & 1 & 0 & 2 & 10 \\
\hline 2 & 2 Jam & 4 & 3 & 4 & 0 & 4 & 20 \\
\hline 3 & 3 Jam & 6 & 6 & 5 & 0 & 6 & 30 \\
\hline 4 & 4 jam & 7 & 8 & 7 & 0 & 7 & 35 \\
\hline 5 & 5 jam & 10 & 11 & 10 & 0 & 10 & 50 \\
\hline 6 & 6 jam & 11 & 12 & 11 & ro & 11 & 55 \\
\hline 7 & $7 \mathrm{jam}$ & 13 & 14 & 13 & 0 & 13 & 65 \\
\hline 8 & 8 jam & 15 & 15 & 14 & (') & 15 & 75 \\
\hline 9 & 9 jam & 15 & 16 & 16 & 0 & 16 & 80 \\
\hline 10 & 10 jam & 18 & 17 & 18 & 0 & 18 & "90: \\
\hline 11 & $11 \mathrm{jam}$ & 18 & 19 & 19 & 0 & "19" & 95 \\
\hline 12 & $12 \mathrm{Jam}$ & 20 & 20 & 20 & 0 & 20 & 100 \\
\hline
\end{tabular}

Tabel 5

Hasil Pengamatan Jentik Aedes aegypti Setelah Pemajanan Dengan Konsentrasi 1,5\% Ekstrak Daun Beluntas Selama 24 Jam Dengan Interval Waktu 1 Jam

\begin{tabular}{|c|c|c|c|c|c|c|c|}
\hline \multirow{2}{*}{ No } & \multirow{2}{*}{$\begin{array}{l}\text { Waktu } \\
\text { (Jam) }\end{array}$} & \multicolumn{3}{|c|}{ Jumlah Kematian Jentik } & \multirow{2}{*}{ Kontrol } & \multirow{2}{*}{$\begin{array}{c}\text { ¿Rata- } \\
\text { rata } \\
\text { kematian } \\
\text { jentik }\end{array}$} & \multirow{2}{*}{$\%$} \\
\hline & & Replikasi & $\underset{\|}{\text { Replikasi }}$ & $\begin{array}{l}\text { Replikasi } \\
\text { III }\end{array}$ & & & \\
\hline 1 & $1 \mathrm{jam}$ & 1 & 2 & 2 & 0 & 2 & 10 \\
\hline 2 & $2 \mathrm{jam}$ & 4 & 3 & 4 & 0 & 4 & 20 \\
\hline 3 & $3 \mathrm{jam}$ & 6 & 5 & 6 & " & 6 & 30 \\
\hline 4 & 4 jam & 10 & 9 & 10 & 0 & 10 & 50 \\
\hline 5 & $5 \mathrm{jam}$ & 12 & 11 & 12 & "'o' & 12 & 60 \\
\hline 6 & 6 jam & 13 & 14 & 13 & 0 & 13 & 65 \\
\hline 7 & 7 jam & 15 & 15 & "'14' & 0 & 15 & 75 \\
\hline 8 & $8 \mathrm{jam}$ & "17' & 16 & 17 & 0 & 17 & 85 \\
\hline 9 & 9 jam & 18 & 17 & 18 & 0 & 18 & 90 \\
\hline 10 & $10 \mathrm{jam}$ & 19 & 18 & 19 & 0 & 19 & 95 \\
\hline 11 & $11 \mathrm{jam}$ & 20 & 20 & 20 & ' & 20 & 100 \\
\hline
\end{tabular}

Grafik 1

Hasil Rata-Rata Kematian LT50 Jentik Aedes aegypti Setelah Pemajanan Ekstrak Daun Beluntas

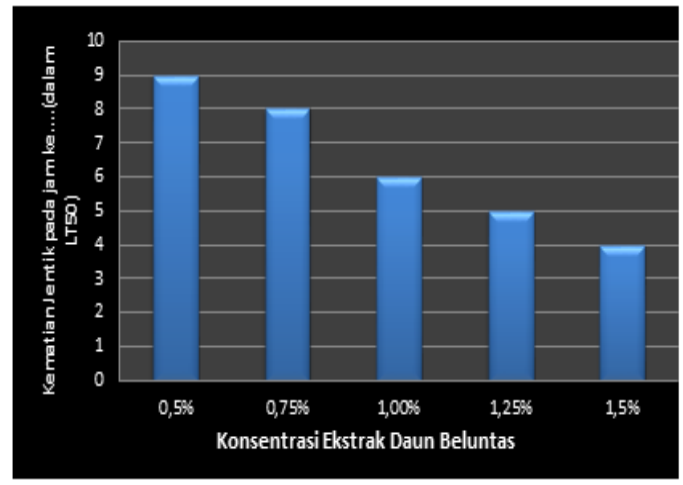

\section{PEMBAHASAN}

Salah satu tumbuhan yang dapat di gunakan sebagai insektisida nabati adalah daun beluntas (Pluchea indica linn), tanaman ini mengandung senyawa aktif yang teridentifikasi dalam daun beluntas mengandung alkaloid, flavonoida, saponin, tanin, minyak atsiri yang dapat digunakan sebagai larvasida dalam mematikan jentik.

Berdasarkan hasil penelitian yang telah dilakukan, maka dapat dijelaskan bahwa ekstrak daun beluntas (Pluchea indica linn) mampu dalam mematikan jentik Aedes aegypti. Dan pada kontrol tidak terdapat kematian jentik selama percobaan dilakukan.

1. Kemampuan ekstrak daun beluntas dengan konsentrasi $0,5 \%$

Setelah percobaan yang dilakukan pada jentik Aedes aegypti instar III dengan menggunakan ekstrak daun beluntas pada konsentrasi 0,5 Lethal Time $50 \quad\left(\mathrm{LT}_{50}\right)$ tercapai setelah 9 jam dimana jentik Aedes aegypti yang mati sebanyak 10 ekor (50\%) kematian jentik.

2. Kemampuan ekstrak daun beluntas dengan konsentrasi $0,75 \%$

Setelah percobaan yang dilakukan pada jentik Aedes aegypti instar III dengan menggunakan ekstrak daun beluntas pada konsentrasi $0,75 \%$ Lethal Time 50 (LT $\left.{ }_{50}\right)$ tercapai setelah 8 jam, dimana jentik Aedes aegypti yang mati mencapai 10 ekor (50\%), .

3. Kemampuan ekstrak daun beluntas dengan konsentrasi $1,00 \%$

Setelah percobaan yang dilakukan pada jentik Aedes aegypti instar III dengan menggunakan ekstrak daun beluntas pada konsentrasi $1,00 \%$ Lethal Time 50 (LT50) 
Jurnal Sulolipu : Media Komunikasi Sivitas Akademika dan Masyarakat

Vol. 20 No. 12020

e-issn : 2622-6960, p-issn : 0854-624X

tercapai setelah 6 jam, dimana jentik Aedes aegypti yang mati mencapai 11 ekor (55\%).

4. Kemampuan ekstrak daun beluntas konsentrasi $1,25 \%$

Setelah percobaan yang dilakukan pada jentik Aedes aegypti instar III dengan menggunakan ekstrak daun beluntas pada konsentrasi $1,25 \%$ Lethal Time $50 \quad\left(\mathrm{LT}_{50}\right)$ tercapai setelah 5 jam, dimana jentik Aedes aegypti yang mati mencapai 10 ekor (50\%).

5. Kemampuan ekstrak daun beluntas dengan konsentrasi $1,5 \%$

Setelah percobaan yang dilakukan pada jentik Aedes aegypti instar III dengan menggunakan ekstrak daun beluntas pada konsentrasi 1,5\% Lethal Time 50 (LT 50$)$ tercapai setelah 4 jam.

Menurut Asimayu (2003), daun beluntas merupakan salah satu tumbuhan yang memiliki kandungan senyawa alkaloid, tanin, flavonoid, saponin, natrium, minyak atsiri, kalsium, fosfor, asam amino (leusin, triptofan, treonin, isoleusin), vitamin A dan C. Kandungan tanin, flavonoid, saponin pada tanaman beluntas dapat menyebabkan gangguan pencernaan yang akan mempengaruhi pertumbuhan hewan yang di ujikan tersebut.

Saponin memiliki aksi sebagai insektisida dan larvasida yang dapat menurunkan tegangan permukaan selaput mukosa traktus digestivus larva dan dinding traktus digetivus larva menjadi korosif sehingga menyebabkan gangguan pada sistem pernapasan larva.

Tanin merupakan senyawa aktif yang diketahui sebagai racun perut, tanin dapat masuk kedalam tubuh larva Aedes aegypti melalui sistem pencernaan dan menyebabkan mekanisme penghambat daya makan pada larva. Hal ini akan mengakibatkan terjadinya aktivitas mendadak pada saraf pusat sehingga menyebabkan larva mati.

Minyak atsiri merupakan salah satu senyawa metabolit sekunder yang mudah menguap (volatil) dan bukan merupakan senyawa murni tetapi tersusun atas beberapa komponen yang mayoritas berasal dari golongan terpenoid. Minyak atsiri terdiri dari campuran zat yang mudah menguap dengan komposisi dan titik didih yang berbeda beda. Minyak atsiri yang mudah menguap terdapat dalam kelenjar minyak khusus didalam kantung minyak atau di dalam ruang antar sel dalam jaringan tanaman.

Alkaloid sebagai antibakteri yaitu dapat menghambat pembentukan peptidoglikan pada sel bakteri sehingga lapisan dinding sel pada sel bakteri tidak terbentuk secara utuh. Dan dapat menghambat daya makan pada hewan uji karena kandungan alkoloid pekat sehingga nutrisi jentik berkurang dan menyebabkan kematian.

Nyamuk termasuk dalam kelompok serangga yang mengalami metamorposis sempurna dengan bentuk siklus hidup berupa telur, larva (beberapa instar), pupa, dan dewasa. (Sembel, 2009). Masa hidup nyamuk Aedes aegypti terbilang singkat, yakni rata-rata 8 hari untuk nyamuk dewasa. Namun, masa kini hidup nyamuk itu akan lebih panjang pada musim hujan, dengan tingkat penyebaran virus juga semakin meningkat (Putri, 2016).

Pemusnahan vektor penyakit bahwa telur-telur Aedes aegypti dapat bertambah dalam waktu lama terhadap desikasi pengawetan dengan pengeringan, kadang lebih dari satu tahun (Soengijanto, 2006). Bila perkembangan pupa sudah sempurna yaitu sesudah 2 atau 3 hari, maka kulit pupa pecah dan nyamuk dewasa keluar serta terbang. (Ahmad et.all, 2013). Penyakit ini disebabkan oleh suatu virus yang menyebabkan gangguan pada pembuluh darah kapiler dan pada sistem pembekuan darah, sehingga mengakibatkan pendarahan. Vektor yang berperan dalam penularan penyakit ini adalah nyamuk Aedes aegypti (Moko, 2015).

Dari hasil penelitian yang telah dilakukan kematian jentik setelah dipaparkan dengan ekstrak daun beluntas dapat dinyatakan bahwa konsentrasi yang paling mampu dalam mematikan jentik Aedes aegypti dan memenuhi standar $\mathrm{LT}_{50}$ yaitu konsentrasi $1,5 \%$. Lethal Time 50 (LT50) tercapai setelah 4 jam, dimana jentik Aedes aegypti yang mati mencapai 10 ekor (50\%).

Sejalan dengan penelitian sebelumnya (Mursalim, 2017) yaitu konsentrasi yang paling mampu dalam mematikan jentik Aedes aegypti yaitu konsentrasi $1,00 \%$ yang telah memenuhi standar $\mathrm{LC}_{50}$ tercapai setelah 4 jam, dimana ratarata kematian jentik Aedes aegypti yang mati mencapai 15,33 yaitu $(61,33 \%)$.

Sejalan dengan penelitian sebelumnya (Susilawaty 2017) yaitu konsentrasi yang paling mampu dalam mematikan jentik Aedes aegypti yaitu konsentrasi $0,386 / 100 \mathrm{ml}$ yang telah memenuhi standar $\mathrm{LT}_{50}$ tercapai setelah menitke480 diperoleh $74.86 \%$ kematian larva Aedes aegypti.

Dari semua konsentrasi yang telah diuji cobakan yang baik untuk diterapkan yaitu pada konsentrasi $0,5 \%$ karena kandungan ekstrak daun beluntasnya masih rendah sehingga perubahan pada air menjadi keruh dan agak kecoklatan tetapi tidak pekat dan perubahan baunya tidak terlalu menyengat 
Jurnal Sulolipu : Media Komunikasi Sivitas Akademika dan Masyarakat

Vol. 20 No. 12020

e-issn : 2622-6960, p-issn : 0854-624X

sehingga layak untuk diterapkan di masyarakat untuk membasmi jentik nyamuk Aedes aegypti.

\section{KESIMPULAN}

1. Semakin tinggi konsentrasi ekstrak daun beluntas pada dalam mematikan jentik Aedes aegypti waktu yang diperlukan memenuhi Lethal Time 50 (LT50) juga akan semakin sedikit.

2. Setiap konsentrasi ekstrak daun beluntas dinaikkan $0,25 \%$ maka waktu yang diperlukan untuk memenuhi Lethal Time 50 (LT50) juga berkurang 1 jam

\section{SARAN}

Kepada pihak yang terkait agar dapat mempromosikan larvasida dengan menggunakan bahan alami yaitu ekstrak daun beluntas dalam pengendalian jentik nyamuk Aedes aegypti. Diharapkan masyarakat dapat memanfaatkan ekstrak daun beluntas sebagai larvasida jentik nyamuk Aedes aegypti. Bagi peneliti selanjutnya ekstrak daun beluntas dapat juga diujikan pada jenis jentik lainnya seperti jentik Anopheles Sp ataupun Culex Sp.

\section{DAFTAR PUSTAKA}

Ahmad Hamsir et.all. 2013 Pengendalian Vektor dan Binatang Pengganggu-A, Makassar: Politeknik Kesehatan Makassar Jurusan Kesehatan Lingkungan.

Andi Susilawaty, 2017. Efektifitas Larvasida Ekstrak Kulit Buah Jeruk Nipis (Citrus aurantifolia) Dalam Membunuh Jentik Nyamuk Aedes sp. (online), vol. 3, No.2, (repository.uinalauddin.ac.id/view/year/2017, diakses 04 januari 2019).

Ariani Putri Ayu, 2016. Demam Berdarah Dengue. Yogyakarta: Nuha Medika.

Asimayu, 2003. Pengaruh Pemberian Ekstrak Daun Beluntas Terhadap Total Kolesterol Darah Broiler. Jurnal Penelitian Pertanian Terapan vol. 14 No. (3), hlm 153 (download.garuda.ristekdikti.go.id, diakses 04 Januari 2019).

Hafidz anditya, 2017. Makalah Pengendalian Nyamuk Aedes Aegypti. (Online). (www.andityahafidz.blogspot.com diakses 04 januarl 2019).

Moko. Mauliddin, 2015. Penularan dan Siklus Hidup Virus Dengue Sebagai Penyebab DBD. (Online) (htpps://garisbatas.com/penyebab-dan-penularan-dbd. diakses 04 Januari 2019).

Nur Afiaty Mursalim, 2017. Efektifitas Ekstrak Daun Beluntas Sebagai Larvasida Aedes aegypti Instar III (Skripsi tidak diterbitkan) Fakultas Kedokteran Dan IImu Kesehatan UIN Alauddin Makassar. (Online) (repository.uin-alauddin.ac.id, diakses 04 Januari 2019).

Putri, Nadia 2016. Buku Pintar Virus Zika. Yogyakarta: Flasbooks.

Sembel Dantje. T, 2009. Entomologi Kedokteran. Yogyakarta: Andi

Soegijanto, Soegeng. 2006. Demam Berdarah Dengue. Surabaya: Unair (AUP) 